\title{
The Application of Domestication and Foreignization Strategies in Translating Arabic-English Collocations in Awlad Haratina's Novel
}

\author{
ADHAM MOUSA OBEIDAT \\ School of Languages, Literacies, and Translation \\ Universiti Sains Malaysia \\ adham.translate@gmail.com
}

\begin{abstract}
This paper examines the translations of collocations in a literary text in light of the translation strategies used within the framework of Venuti's foreignization and domestication strategies. The study aims to examine the translation strategies that are frequently employed to translate collocations. It also attempts to find out if the translators of the TTs follow Venuti's preferred strategy of translation, foreignization. Moreover, it investigates if using these strategies resulted in any distortion of the SL message. Accordingly, a comparative quantitative analysis and an expressive interpretive examination are followed to analyze the collected data. The study reveals that foreignization is highlighted by the heavy usage of literal translation, cultural borrowing and descriptive equivalence procedures. Domesticating procedures are manifested in cultural equivalent, addition, reduction, omission and adaption. According to the nearly equal percentage of using the two strategies, the study results in finding that collocations can be translated by using the two strategies, domestication and foreignization depending on the type of the collocation. However, foreignization strategy is used as the most frequent strategy to translate collocations.
\end{abstract}

Keywords: collocations, domestication, foreignization, strategies, procedures, translation

Published online: 31 October 2019

To cite this article: Obeidat A. M. (2019). The Application of Domestication and Foreignization Strategies in Translating Arabic-English Collocations in Awlad Haratina's Novel. International Journal of Language, Literacy and Translation 2(2), 13-28. https://doi.org/10.36777/ijollt2019.2.2.024

To link to this article: https://doi.org/10.36777/ijollt2019.2.2.024 


\section{INTRODUCTION}

Translation strategies play a vital role in translating cultural collocations. Due to the significance of translation strategies, scholars theorized and developed different translation strategies such as those suggested by Newmark (2001), Nida (1964) and Venuti (1995). Translation is a process of transferring meaning from one language into another. Oxford Advanced Learner's Dictionary (2005) defines translation as "the procedure of transferring something that is spoken or written into another language. From this definition, the translation process looks an easy process as it indicates to replace words by words. However, the difficulty of translation arises from the culture or style substitution which cannot be achieved by only replacing words. Nida (1969) states that translation as a process includes the terms of meaning and style as the goal is to reproduce the natural equivalence of the source language message to the target language.

The term collocation was first introduced by Firth, who believes that the meaning of collocation is completely lexical (Firth, 1957, p. 195). For him, the lexical meaning is one of five dimensions of meaning (phonetic, lexical, semantic, morphological and syntactic) (p. 196). Oxford Advanced Learner's Dictionary (2005) defines 'collocation' as "a combination of words in a language that happens very often and more frequently than would happen by chance: 'resounding success' and 'crying shame' are English collocations" (p. 293). Gledhill (2000) defines collocation as "a process by which words combine into larger chunks of expression. Some collocations involve words which seldom occur in other combinations" (p. 9).

The translator of literary works needs not only to be bilingual but also, he/she should have a deep knowledge of the different implications and impacts of the cultural elements used in a literary text. Toury (1995, p. 56) describes translation of literature as an activity which 'inevitably involves at least two languages and two cultural traditions, i.e. at least two sets of norm-systems on each level' A Collocation in a literary text is used as a way of reflecting the culture of the ST, in addition to the reflection of the language use. Such language use includes the way to express figurative meaning as قبي /نملة in Arabic, which equivalently means an inch in English. In this regard, Kalėdaite, \& Palevičienè, (2008) argue that "differences in collocational patterning in different languages reflect the preferences of specific language communities for certain modes of expression. Some collocations are a direct reflection of the material, social, or moral environment in which they occur. This explains, for example, why bread collocates with butter in English, but not in Arabic (p. 88). Since collocations are used naturally by the speakers of any language, then they have important functions to make the text more cohesive, to clearly convey the writer's intention and to create new figurative images to the reader.

The variety of different lexical items that occur together in a literary text makes their translation challengeable as some combinations of words may have a meaning that differs from the meaning of the individual word. A literal translation of such collocation may result in meaning loss or mistranslation of collocation, for example, فلذة الكبد should not be translated as $a$ part of a lever. Such literal translation destroys the meaning completely, in addition to making such translation looks odd for target readers. Thus, translators need to pay more attention to the procedures of translating collocations to avoid making the collocation look odd to the receptor readers and to make it appear as a natural impression. However, literal translation succeeds, in some cases, to render the open-ended collocations which have no intended meaning such as (the war started). The meaning of such collocation can be obtained from the dictionary meaning of the collocation components. 
By investigating cultural collocations in a literary work and its translation, the present study aims to apply the strategies of domestication and foreignization to the selected collocations and examining if those collocations are domesticated or foreignized in the target texts. The researchers apply Venuti's (1995) model of domestication and foreignization to investigate the procedures that are employed to domesticate or foreignize collocations. The study also aims at finding if collocations in the literary text should be domesticated or foreignized to achieve the best equivalence in the target text (TT). In other words, the objective is to shed light on collocation translation as an attempt to bridge the gap between the two languages subject of this paper i.e. Arabic and English.

\section{LITERATURE REVIEW}

Venuti (1995) believes that the domestication strategy is a strategy that deals with culture. He divides this strategy into two main steps, first, to choose a foreign text or a cultural element of this text, and second, to find an adequate translation method to convey this cultural element into the target text. In this strategy, what is domesticated is the form and content. On the contrary, foreignization follows the same steps of the domestication strategy. However, what is foreignized is only the content, while the form is mostly domesticated.

Venuti's model is based on the different methods of translation suggested by Schleiermacher, who believes that "in translation, the translator either leaves the author in peace, as much as possible, and moves the reader towards him, or he leaves the reader in peace and moves the author towards him" (Schleiermacher, 1813, cited in Venuti, 1995, p. 19).

According to Venuti (1995) domestication is "an ethnocentric reduction of the foreign text to receive cultural values, bringing the author back home" (p.20), whereas foreignization is "an ethno deviant pressure on those values to register the linguistic and cultural differences of the foreign text, sending the reader abroad" (Venuti, 1995, p. 20). He prefers to use foreignization as a strategy of translating cultural texts due to the need to "signify the linguistic and cultural differences of the foreign text" (p. 23). Moreover, this strategy can change how translation is conceived and created since it implies the notion of human subjectivity that differs from the humanist assumptions involved in domestication (Venuti 1995 as cited in Obeidat \& AbuMelhim, 2017 p. 53).

Indeed, translating collocations from Arabic into English is not an easy task since they have their own characteristics in language use, word choice, cultural concepts, idiomatic meaning and so forth. Accordingly, when a literary text is translated into the target language certain factors should be taken into consideration. As the source text of this study is translated for the purpose of literature and transferring the source text (ST) culture into TT culture, translators have to pay more attention to the collocations in terms of word choice and cultural signs. Many translated literary texts suffer in quality due to linguistics, semantic, pragmatic or stylistic errors.

Munday (2001) defines the domestication strategy as a type of translation, where the elements of the ST foreign elements are reduced into the receiving language cultural values (p. 225). On the other extreme, foreignization is illustrated by keeping the foreign values of the source text in the translated version (Shuttelworth \& Cowie, 1997, p. 59). An example of the difference between the two concepts in the two languages subjects of this study is the collocation, يغض الطرف (Yaghudu al-Tarf) which literally means: ignoring something / someone. To domesticate this collocation into English, a translator may use the procedure of dynamic equivalence and 
translate it into "turned a blind eye". Any other translation of these collocations, such as the literally on, will be the foreignization strategy, for example, lower his eyebrows.

Yang (2010) comments that "domestication and foreignization are two basic translation strategies which provide both linguistic and cultural guidance for the translator in rendering cultural- specific source texts into parallel target texts" (p. 1). Obeidat and Mahadi (2019) argue that "domestication and foreignization are two important strategies in translating cultural collocations" (p. 155). Moreover, Munday (2001) states that "domestication and foreignization answer the question of how to bridge the gulf that had grown between the writer or the sourcetext which is written in a language that is very culture-bound and the target- text writer" (p. 242). Thus, the debate of these two strategies is not about the linguistic form. They expand beyond the linguistic boundaries to be more concerned with cultures (Sharifabad, Yaqubi \& Mahadi, 2013, p. 96).

In the most recent studies of domestication and foreignization which have been applied in translation, Obeidat and Abu-Melhim (2017) use Venuti's model to examine the translation of baby formula labels in the light of domestication and foreignization strategies. The research focuses on investigating the translation strategies that are frequently employed in the translation of baby formula labels. Findings of the study reveal that foreignization is highlighted through the heavy usage of literal translation, transliteration, borrowing and transference. On the other hand, translation strategies that belong to domestication are transposition, omission, addition and adaption.

Sharifabad, Yaqubi and Mahadi (2013) apply these strategies on the translation of news phrasal verbs. The study aims to investigate whether the translators tend to domesticate the news headlines or foreignize them. The result shows that the translators tend to apply the domestication strategy more frequently. The study finds that since cultural-specific terms and words are difficult to understand in the target language, the translators mostly tend to localize or domesticate them.

Al-Rikaby, Mahadi and Lin (2018) conduct their study to apply the domestication and foreignization strategies on translating the proper nouns and cultural-bound terms. They find that the translator favoured using foreignization strategy. They also concluded that although there is evidently a healthy inclination towards domestication, foreignization is the more pervasive method.

Translating collocations starts by recognizing them in the source language (SL) and then rendering them conveniently (Hatim \& Munday, 2004, p. 249). According to Newmark (1988), the struggle of translating a collocation starts by (1) recognizing the collocation, (2) the ability of the translator to read the ST collocation as one meaningful unit, (3) finding an appropriate equivalence.

The process of finding the appropriate equivalence of the ST collocations means to launch a process of connecting appropriate nouns with verbs, verbs with nouns, adjectives with nouns and verbs with appropriate adverbial groups (Newmark, 1988, p. 213). Potentially, collocations are either lexical or grammatical. On one hand, the lexical collocations are composed of two or more content words i.e. nouns, verbs, adjectives and adverbs. On the other hand, grammatical collocations refer to the combinations comprising a content word and a function word, which is usually a preposition (Benson, Benson \& Ilson, 1997).

Translators adopt many strategies to overcome the problem of translating collocations such as simplification, reduction, synonymy and paraphrasing. Although linguists state that the translator should be faithful in translating a collocation, some linguists feel that rendering the ST 
collocation into a collocation in the TT will result in a collocation which is "unnatural and obscure" (Cowan, 1989, p. 56). However, this kind of unnatural collocation in the TT is sometimes necessary. The necessity of such translation arises from the fact that the target language has no equivalence or there are no other ways to render it.

In the light of the above-mentioned studies, this study focuses on examining the translations of collocations used in a literary text in the light of translation strategies used within the framework of Venuti's model of domestication and foreignization. It also aims to investigate the translation procedures that frequently adapted in the translation of these collocations. Accordingly, it is basic for translators to be familiar with the different procedures when translating collocations. Based on this, this study attempts to answer the following questions:

1- What is the most frequent strategy that has been employed by the English translators to translate collocations in this literary text?

2- What are the procedures used by translators to domesticate or foreignise collocations?

\section{METHOD OF THE STUDY}

\section{TEXTS}

The data which are used in this study consist of the collocations mentioned in the Arabic Novel "او لاد حارتنا، based on Venuti's Model of Domestication and foreignization and its English translations by Philip Stewart (1981) and Peter Theroux (1988). "او لاد حارتنتال (Awlad Haratina) is a famous novel written by the famous Egyptian writer Naguib Mahfooz. This Novel was first published in Arabic in 1959 in a serialized form by the daily newspaper Al-Ahram. The first printed book of this novel was in Lebanon in 1967. The first translation "Children of Gebelawi" was done by Philip Stewart in 1981 and was published for the first time in 1981 by Heinemann Educational Book (London). It is still in printing up to this date in a book form which consists of 355 pages. Stewart is a British translator, who studied Arabic literature. This novel was his first book of translation in 1981. The Second Translation "Children of the Alley was done by Peter Theroux in 1988 after Stewart refused to sell his copyright of the translated novel. The first published version was done in the United States in 1988 by Anchor Books, it was printed in a book form which consists of 448 pages. Theroux is an American translator, who studied the Arabic Language in Egypt for one year. After that, he became interested in translating Arabic literature. He translated many novels for Egyptian, Iraqi and Lebanese writers.

\section{PROCEDURES}

The methodology of this study is an expressive interpretive examination of the ST and TTs collocations. A comparative quantitative analysis was conducted to examine the corpora of the study. The chosen collocations relate to different types of collocation: restricted, bound, idiomatic and open collocations as suggested by Emery (1991). The system of this study begins with the identification of all the collocations mentioned in the ST manually by reading the ST and highlighting its collocations. The method of choosing collocation is conducted based on the co-occurrence of words and phrases such as verb+ noun, noun + noun, noun + adjective, etc. The found collocations are examined if they exist as collocations by using Arabicorpus website 
which provides a series of collocating words to a certain word. The TTs are read to identify the English equivalent collocations. The found collocations are counted manually, then they are examined based on the procedure that is used in the translation. The number of frequent occurrences of each procedure is taken into consideration to assess the percentage of the usage of each procedure. The translations of these collocations are compared to their equivalents in the ST to point out the translation strategies involved in the translation process. Accordingly, the translation procedures that were employed are categorized in terms of foreignization and domestication strategies which consist of the theoretical framework of the study.

\section{FINDINGS}

The detailed analysis of Arabic collocations and their English translations shows that the translators employed eight translation procedures in the translation of the identified samples. The domestication strategy contains the procedures of cultural equivalence, addition, reduction, omission and adaption. On the other hand, foreignization strategy contains literal translation, cultural borrowing and descriptive equivalence. The categorizing of those procedures as domestication or foreignization procedures refers to the fact if the translated collocation exists in the TL as a collocation or not, if the translated collocation reflects the ST culture or the TT culture and if the translated collocation convey the meaning equivalently. The aforementioned procedures are classified under foreignization and domestication strategies as shown in the following table:

Table 1

Frequency of Domestication and Foreignization Procedures

\begin{tabular}{llllll}
\hline Foreignization & Frequency & \% & Domestication & Frequency & \% \\
\hline Literal translation & 320 & 87 & Cultural equivalent & 95 & 36 \\
\hline Cultural borrowing & 9 & 2 & Addition & 42 & 15 \\
\hline $\begin{array}{l}\text { Descriptive } \\
\text { equivalence }\end{array}$ & 36 & 11 & Reduction & 60 & 6 \\
\hline & & & Omission & 23 \\
\hline & & Adaption & 15 & 20 \\
\hline Total: & 365 & 50 & 262 & 10 \\
& & & & 0 \\
\hline
\end{tabular}

As shown in the table (1) above, all the used procedures are studied based on their frequent occurrence. The strategies of domestication and foreignization are adopted 627 times in the examined collocations. Nevertheless, foreignization strategy is more frequently used and consists of the dominant strategy that occurs 365 times (58\%). On the other hand, domestication strategy is the least used strategy that accounts 262 frequencies on (42\%) out of the total number of the translated collocations. The higher percentage of using foreignization strategy refers to the high usage of literal translation to translate different types of collocations. The following table shows 
IJoLLT Vol. 2, No. 2 (September) 2019

eISSN: 2637-0484

the total number of occurrences of the domestication and foreignization strategies and their percentages:

Table 2

Overall Frequency of Domestication and Foreignization Strategies

\begin{tabular}{lcc}
\hline Translation Strategy: & Number of occurrences: & Percentage: \\
\hline Domestication & 262 & $42 \%$ \\
\hline Foreignization & 365 & $58 \%$ \\
\hline Total: & 627 & 100 \\
\hline
\end{tabular}

As aforementioned, the corpus of this study consists of two English translations. Every translator has his own strategies for translating collocations. The two translators share the feature of applying the domestication and foreignization by employing the aforementioned eight procedures. The following tables show the percentage of each procedure used by each translator:

Table 3

Domestication procedures employed by the two translators

\begin{tabular}{|c|c|c|c|c|c|c|}
\hline \multirow[t]{2}{*}{ Procedure: } & \multicolumn{2}{|c|}{ 1st translation } & \multicolumn{2}{|c|}{ 2nd translation } & \multirow[t]{2}{*}{ Total Freq: } & \multirow[t]{2}{*}{$(\%)$} \\
\hline & Freq & $\%$ & Freq & $\%$ & & \\
\hline Cultural equivalent & 35 & $34 \%$ & 60 & $38 \%$ & 95 & $36 \%$ \\
\hline Addition & 19 & $18 \%$ & 23 & $15 \%$ & 42 & $15 \%$ \\
\hline Reduction & 28 & $28 \%$ & 32 & $20 \%$ & 60 & $23 \%$ \\
\hline Omission & 5 & $4 \%$ & 10 & $6 \%$ & 15 & $6 \%$ \\
\hline Adaption & 17 & $16 \%$ & 33 & $21 \%$ & 50 & $20 \%$ \\
\hline Total: & 104 & $100 \%$ & 158 & $100 \%$ & 262 & $100 \%$ \\
\hline
\end{tabular}

Table 4

Foreignization Procedures employed by the two translators

\begin{tabular}{|c|c|c|c|c|c|c|}
\hline \multirow[t]{2}{*}{ Procedure: } & \multicolumn{2}{|c|}{ 1st translation } & \multicolumn{2}{|c|}{ 2nd translation } & \multirow[t]{2}{*}{ Total Freq: } & \multirow[t]{2}{*}{ (\%) } \\
\hline & Freq & $\%$ & Freq & $\%$ & & \\
\hline Literal translation & 215 & $91 \%$ & 105 & $81 \%$ & 320 & $87 \%$ \\
\hline Cultural borrowing & 4 & $2 \%$ & 5 & $4 \%$ & 9 & $2 \%$ \\
\hline Descriptive equivalence & 17 & $7 \%$ & 19 & 15 & 36 & $11 \%$ \\
\hline Total: & 236 & $100 \%$ & 129 & $100 \%$ & 365 & $100 \%$ \\
\hline
\end{tabular}


The tables $(3 \& 4)$ show that the two translators have different percentages in applying the translation procedures. In terms of domestication strategy, the first translator relied more on the cultural equivalent 35 times or (34\%), while the second translator used it 60 times or (36\%). The table indicates that the two translators were almost equal in employing the same procedure to achieve an adequate translation. The figures of foreignization procedures show that the first translator uses literal translation more frequently as a preferred procedure to translate collocations. He uses it 215 times out of 236 (91\%), while the second translator applies it 105 times out of $129(81 \%)$. The high percentage of using literal translation indicates how translating colocation is a challenging task. Translators apply literal translation procedure due to the different linguistic, semantic and lexical features of the ST and TT.

Based on the mentioned figures and analysis, it seems that the two strategies attract the attention of the translators of the mentioned collocations. However, Venuti's preferred strategy, foreignization, seems to be the frequently used procedure in translating the largest number of the types of collocations understudy: open, restricted, bound and idiomatic. The analysis also shows that translators applied eight procedures to translate collocations namely: cultural equivalent, addition, reduction, omission and adaption, literal translation, cultural borrowing and descriptive equivalence. A brief account of these procedures is discussed by examples in the following section.

\section{DISCUSSION}

\section{DOMESTICATION PROCEDURES}

\section{CULTURAL EQUIVALENCE}

Cultural equivalence "involves replacing a culture-specific item or expression ... with a target language item which describes a similar concept in the target culture and thus is likely to have a similar impact on the target readers" (Paluszkiewicz-Misiaczek, 2005, p. 244). It is a functional procedure in translating literary texts since it "preserve the realistic perspective of the literary texts". (O'Donoghue, 2005, p. 13). The following examples illustrate how translators employed this procedure to fill the gap between the ST and TT.

Table 6

Examples of same translations of cultural equivalent procedure

\begin{tabular}{|c|c|c|c|c|}
\hline ST Collocations: & $1^{\text {st }}$ TT Collocation & Back Translation & $2^{\text {nd }}$ TT Collocation & Back Translation \\
\hline وحد الله & For God's sake & حبا في الله & For God's sake & حبا في الله \\
\hline يسفلك الاماء & Shed any blood & يسفم الدماء & Shed any blood & يسفك الدماء \\
\hline صميم القلب & Bottom of heart & صميم القلب & Bottom of heart & صميم القلب \\
\hline سواء السبيل & Right path & السبيل الصحيح & Right path & السبيل الصحيح \\
\hline ارتكب جريمة & Commit a crime & برتكب دريمة & Commit a crime & برتكب جريمة \\
\hline الفر اخ المحمرة & Roast chicken & الدجاج الدحمر & Roast chicken & الدجاج المحمر \\
\hline
\end{tabular}


Tables (6) shows how both translators employ the same translation procedure for the selected collocations. This indicates how a culture equivalent of the ST collocations exists in the TT. Cultural equivalence plays an essential role when the two cultures share the same collocation. Furthermore, the two translators have different equivalents to other selected collocations; however, translators still use the culture equivalent procedure as shown in the following table:

Table 7

Examples of different translations of cultural equivalent procedure

\begin{tabular}{|c|c|c|c|c|}
\hline ST Collocations: & $1^{\text {st }}$ TT Collocation & Back translation & $2^{\text {nd }} T T$ Collocation & Back translation \\
\hline دنيا الفتونة & The world of men & عالم الرجال & The world of chiefs & عالم الرؤساء \\
\hline غر اب بين & Cawing crow & غر اب ينعق & Owl amongst ravens & كالبومة بين الغربان \\
\hline أب جبار & Tyrant father & الاب الجبار & Terrible father & الاب الفضيع \\
\hline لعنة الله & God's damn & لعنة الله & God's curses & لعنة الله \\
\hline
\end{tabular}

ADDITION

Newmark (1988) states that addition is used when a translator adds information to elaborate on the meaning in context. Usually, a translator uses this procedure to convey a meaning of a cultural word, technical word or a linguistic problem. The added information may appear in various forms in a text. A translator may add this information within the text, notes at bottom of page, notes at end of chapter, notes or glossary at the end of the book. In the case of literary texts, translators avoid footnotes or glossaries and add the needed information directly to the text. ST collocations, which have no equivalence in TT, are translated by adding information in translation.

Although ST collocations should be translated into collocations in the TT, addition is an effective procedure which can give the reader more elaboration about the text. The following table will explain how translators use addition in translating ST collocations:

Table 8

Examples of Addition procedure

\begin{tabular}{|c|c|c|c|c|}
\hline ST Collocations: & $1^{\text {st }}$ TT Collocation & Back translation & $2^{\text {nd }}$ TT Collocation & Back translation \\
\hline الطو اف بييته & Stroll around the tall mansion & الطويل حول القصر & Walk around the big house & يمشي حول البيت الكبير \\
\hline يبرح مكانه & Without leaving his place & دكانه ان يتحرك من & $\begin{array}{l}\text { Without moving from the } \\
\text { spot }\end{array}$ & بقعته ان بتحرك من \\
\hline يهضم الحقوق & $\begin{array}{l}\text { Rights that cannot be put } \\
\text { aside }\end{array}$ & تجنبها الحقوق التي لا بمكن & $\begin{array}{l}\text { Rights that cannot be set } \\
\text { aside }\end{array}$ & تجنبها \\
\hline
\end{tabular}




يتقبل القدر بصمت

The given examples illustrate how translators find it challenging o translate ST collocations into TT collocations. The two translators used this procedure by adding other words to convey the collocational meaning equivalently. For example, الطواف بيتيا, is translated as stroll around the tall mansion. The translator uses two words to translate يطوف, and uses two words to describe the word بيت On the other hand, the words tall or big are not mentioned in the ST collocations. The translators add those adjectives to refer to the house mentioned in the ST.

\section{REDUCTION}

Reduction is the omission of information considered to be unnecessary or unlikely to make sense to the target language reader. It is in line with Newmark $(1988$, p. 90) in which reduction is used to make simplicity in creating meaning. A translator has the chance in translating a collocation by one word as the main goal is the meaning. The following table shows how the meaning of the ST collocation was conveyed by a single word in the TT:

Table 9

Examples of Reduction procedure

\begin{tabular}{|c|c|c|c|c|}
\hline ST Collocations: & $1^{\text {st }}$ TT Collocation & Back translation & $2^{\text {nd }}$ TT Collocation & Back translation \\
\hline ل & Depressed & مكتئب & Wronged & مظلوم \\
\hline ناء بظلم & Suffering & بعاني & Injured & مجروح \\
\hline قطاع الطريق & Lawlessness & خارجين عن القانون & Banditry & قطع الطريق \\
\hline الأرض الو اسعة & The world & العالم & The world & العالم \\
\hline هام على وجهه & Wandered & هائم & Wandered & هائم \\
\hline يهدي السبيل & Guide & يرشد & Lead & يقود \\
\hline ولى هاربا & Ran & يركض & fled & بهرب \\
\hline
\end{tabular}

Since meaning is an essential part of the translation process; collocational meaning can't be always conveyed by a collocation in the TT. Baker (1992) assumes that "meaning cannot always account for collocational pattering" (p. 52). Accordingly, translators opt to convey the meaning by reducing the ST collocation as shown in the given examples. The target texts are just words and not collocations, however, they still convey the meaning as expressed in the ST.

\section{OMISSION}

This procedure is the least used in this study. It constitutes only $(6 \%)$ of the selected samples. Omission is a procedure where translators delete a word or words from the ST when translating into TT. Usually, it is a procedure to deal with vulgar words or phrases that have no equivalences in the TT. It is estimated to be " Strongly Domesticating; because no trace of the original is left in the TT" (Van Poucke, 2012, p. 147. In the case of collocation, deleting a word is reduction, but omission refers to delete the whole collocations as shown in the following table:

Table 10

Examples of Omission procedure

\begin{tabular}{|c|c|c|c|c|}
\hline ST Collocations: & $1^{\text {st }}$ TT Collocation & Back translation & $2^{\text {nd }}$ TT Collocation & Back translation \\
\hline ل صك الأسماع & Omitted & & Omitted & \\
\hline ليقيك الشر & Deliver from devil & بسلم من الشيطان & Omitted & \\
\hline تمزق القلب & Tearing at my heart & بمزق قلبي & Omitted & \\
\hline
\end{tabular}




\begin{tabular}{|c|c|c|c|c|}
\hline وجها عبوسا & More darkly & اكثر عتمة & Omitted & \\
\hline انعقدت الألسن & Speechless & بلا كلام & Omitted & \\
\hline الرجل الفظ & Omitted & & Damned old monster & الرجل الملعون \\
\hline
\end{tabular}

ADAPTION

This procedure is the last one under the domestication procedures. It refers to the "freest form of translation" (Newmark, 1988, p. 46). Bastin (1988) defines adaption procedure as a kind of oblique translation "which can be used whenever the context referred to in the original text does not exist in the culture of target language" (p. 6). Hence, adaption is a re-creation of the ST collocation features to meet the need of the text function and the recipients' culture. Since adaption violates the faithfulness of translation and ignores the ST form or linguistic features, then it is extremely a domestication procedure. The following table shows how collocations in the ST can be translated according to this procedure:

Table 11

Examples of Adaption Procedure

\begin{tabular}{|c|c|c|c|c|}
\hline ST Collocations: & $1^{\text {st }}$ TT Collocation & Back translation & $2^{\text {nd }}$ TT Collocation & Back translation \\
\hline إلد النزاع & The dispute started & بدأ النزاع & Raging the conflict & احتدم الصر اع \\
\hline اشجن قلبي & Broken heart & قلب مكسور & Heart breaking & قلب منكسر \\
\hline وقفو ا بين يديه & Stood before & يقف امام & Stood in front & يقف امام \\
\hline غضو الابصسار & Cast the eyes down & يخفض عينيه & Looked down & ينظر للاسفل \\
\hline النفس النشوى & Delighted self & النفس المبتهجة & Delighted man & رجل مبتيهج \\
\hline دوت الزغاريد & Trilled with joy & تز غرد بفرح & Women youyous & النساء ........... \\
\hline
\end{tabular}

By examining the above-mentioned examples of adaption procedure, it was found that this procedure is used especially for cultural purposes. It is employed to attract the recipients' attention by substituting a cultural collocation by a commonly used sentence or phrase in the TL. Normally, translators use such procedure to avoid literal translation which may result in mistranslation or which may result in causing confusing the TT collocation.

\section{FOREIGNIZATION PROCEDURES}

\section{LITERAL TRANSLATION}

The use of literal translation is effective in translating some collocations, but it fails to render others. It is one of the most essential procedures of foreignization where the "denotative meaning of words is taken as if it straight from the dictionary, but the grammar is respected" (Dickins, Hervey \& Higgins, 2016, p. 16). Wang (2014) argues that there is a relation between the literal translation and foreignization strategy as the emphasis is on the linguistic and stylistic features of the original text. As early mentioned, literal translation may work as an effective procedure in translating open-ended collocations. On the other hand, the usage of this procedure may result in mistranslation or loss of meaning. Newmark (1988) assumes that using literal translation can be avoided "only when its use makes the translation referentially and pragmatically inaccurate, when it's unnatural, when it will not work" (p. 31).

As shown in table 1, literal translation proves to be a heavily used procedure in translating different types of collocations. Table 4 also shows how it is the most frequently used procedure by the two translators. Table (12) shows how literal translation fails in providing an accurate 
translation in some type of collocation. However, in this study, literal translation is found as an adequate procedure to translate collocations. Table (13) shows some examples of how using this procedure may result in an adequate and accurate translation. The quality of translation, of course, can be accessed based on different criteria as those suggested by House (1997).

Table 12

Examples of inaccurate translation by using literal translation:

\begin{tabular}{|c|c|c|c|c|}
\hline ST Collocations: & $1^{\text {st }}$ TT Collocation & Back Translation & $\begin{array}{l}2^{\text {nd }} \mathrm{TT} \\
\text { Collocation }\end{array}$ & Back Translation: \\
\hline يحدج بنظرة & Held with long gaze & بنظر اليه مطو لا & Gave a long gaze & يعطيه نظرة طويلة \\
\hline مسبلة الجفنين & Cast down the eyes & يلقي بنظره ارضا & Dropped eyelids & مسبلة الجفنين \\
\hline محرم على & Not allowed & غير مسموح & Not allowed & غير مسموح \\
\hline صكت أذنها & Rank out the ears & تؤذي اذنيها & Splitting ears & تفصل اذنيها \\
\hline
\end{tabular}

Table 13

Examples of accurate translation by using literal translation

\begin{tabular}{|c|c|c|c|c|}
\hline ST Collocations: & $1^{\text {st }}$ TT Collocation & Back translation: & $2^{\text {nd }}$ TT Collocation & Back translation: \\
\hline إينين نافنتين & Piercing eyes & عينين ثاقبتين & Piercing eyes & عينين ثاقبتين \\
\hline يقر أ ما في النفس & Read the minds & يقر أ عقو لهم & Read their thoughts & يقر أ افكالر هم \\
\hline يزدرد ريقه & Dry mouth & فم جاف & Swallowed hard & يبتلع بصعوبة \\
\hline ترمقه العيون & Under the eyes & تحت العيون & Followed by pairs of eyes & متبوع بالعيون \\
\hline اغرورقت عيناه & Eyes brimming with tears & عيون مليئة بالدموع & Eyes swam with tears & عيون تسبح بالدموع \\
\hline يدركني الموت & Death claims me & يدعوني الموت & Before I die & قبل ان اموت \\
\hline
\end{tabular}

The two tables provide examples of how literal translation is used as an effective procedure in some situations and how it could result in a loss meaning in others. However, this study concludes that literal translation is an essential procedure in translating collocations, and it sounds ideal since other strategies may not reflect the intended message simply and naturally as it is.

\section{CULTURAL BORROWING}

Cultural borrowing is a technique of translation where a word is taken directly from the SL to be a word in the TL (Molina \& Albir, 2002: 520). In the case of cultural borrowing, words are taken from the SL and translated using the words in the TL indicating things or event, which is not the same but occurs in the TL ((Molina \& Albir, 2002: 521). In borrowing, what is foreignized is the word itself, but the form and spelling are made to fit the target language which results in domesticating the form such as Silk Galabiyas. The foreign word Galabiya is borrowed from the SL and it is turned to be a plural noun by adding "s". Such example indicates how the word is domesticated in the form to fit the TL syntactic system.

In the case of collocations, the following examples show how translators borrow a word from the SL and choose an accompanying word in the TT to fit the borrowed word. 
IJoLLT Vol. 2, No. 2 (September) 2019

eISSN: 2637-0484

Table 14

Examples of Cultural Borrowing Procedure

\begin{tabular}{|c|c|c|c|c|}
\hline ST Collocations: & $1^{\text {st }} T T$ Collocation & Back translation: & $2^{\text {nd }}$ TT Collocation & Back translation: \\
\hline جلاليب حريرية & Silk galabiyas & جلابيات حريرية & Silksmocks & \\
\hline دوت الزغاريد & Trilled with joy & & Women youyous & النساء بويو \\
\hline يخرط ملوخية & Chopping moloukhia & تقطع المولحية & Chopping jute leaves & \\
\hline يقطع الحشيش & Cut the hashish & يقطع الحشبش & Cut up hashish & يقطع الحشيش \\
\hline قرقرة الجوزة & Gurgle of Goza & قرقرة:لجوزة & Gurgle of the pipe & \\
\hline انغام الربابة & Ausic of the fiddle & & Melody of rababah & انغام الربابة \\
\hline حشاش قارح & Addicted & & Real hashish addicted & مدمنحشيش حقيقي \\
\hline النقاب الأبيض & White veil & & White niqab & نقاب ابيض \\
\hline
\end{tabular}

The table shows how translators use cultural borrowing in their translation in nine (9) occurrences. The translation still has the feature of collocations by choosing an appropriate word to accompany the borrowed word as in Gurgle of Goza. This collocation is half borrowed as the first word is domesticated as an English word, while the second is a borrowed word which means the pipe.

\section{DESCRIPTIVE EQUIVALENCE}

Newmark (1988) describes descriptive equivalence as a translation procedure to describe the meaning of the source language word/words. Mostly, this procedure is used when the source word or expression is closely related to the distinctive SL culture and the use of cultural equivalents will not provide the needed accuracy in the TT. The following table will show how translators use this particular procedure in their translation of collocations:

Table 15

Examples of Descriptive Equivalence Procedure

\begin{tabular}{|c|c|c|c|c|}
\hline ST Collocations: & $1^{\text {st }}$ TT Collocation & Back translation: & $2^{\text {nd }}$ TT Collocation & Back translation \\
\hline أم أم الدنيا & The most important place & لهمبكلن في للعللم & The mother of world & \\
\hline دخول الكتّاب & Knowing how to write & يعرف كيف يكتب & Going to school & بذهب الى المدرسة \\
\hline ل فلذة كبد & Closest people to & اقرب الناس اليه & The loved ones & احب الناس \\
\hline بواب البيت & $\begin{array}{l}\text { Gatekeeper of the } \\
\text { mansion }\end{array}$ & حارس بو ابو القصر & $\begin{array}{l}\text { The gatekeeper of the } \\
\text { great house }\end{array}$ & حارس بو ابة البيت الكبير \\
\hline سبحة طويلة & Long loop worry beads & حلقة طويلة من الخرز & Long rosary & سبحة طويلة \\
\hline النزع الأخير & Life was finally at end & الحياة كانت في النهاية & Final break of life & اخر جزء من الحياة \\
\hline
\end{tabular}

The table shows how translators use deceptive equivalence to translate cultural collocations which are well known in the SL. The two translators used different words to describe these collocations to give the recipients a close image of this collocation. The collocation الد is a famous one in the Arabic culture which refers to Egypt as the mother of the world. The first translator tried to describe this collocation by describing Egypt as the most important place in the world. The second translator uses literal translation procedure which makes this translation looks odd to the readers in the TT, the mother of world, especially that such collocation is not known to them. 


\section{CONCLUSION}

In order to have a reliable assessment of translating collocations in the light of domestication and foreignization. This study examines different types of collocations that are found in the text. The study reveals that the two translators employed the two strategies, domestication and foreignization, in an attempt to achieve an accurate translation. The discussion shows that the two strategies have a vital impact on the translation itself. Domestication makes the translation more natural for the TL readers, while foreignization plays the role of bringing the ST culture into the TL culture. The study also finds that the two translators employed eight translation procedures: cultural equivalent, addition, reduction, omission and adaption, literal translation, cultural borrowing and descriptive equivalence. Under foreignization strategy, three translation procedures are employed: literal translation, cultural borrowing and descriptive equivalence. Literal translation is the most frequent procedure that has been employed by the translators. On the other hand, foreignization strategy is the most frequent strategy that has been employed by the translators.

This paper discusses the translation of Arabic collocations into English and outlined how a collocation is domesticated or foreignized. The study limits itself to examine the collocations that are found in the corpora of the study. The researcher recommends studying the collocations that have cultural signs and aspects to achieve a better understanding of the notion of collocations in Arabic.

\section{REFERENCES}

Al-Rikaby, A. B. M., Mahadi, T. S. T., Lin, A., \& Tan, D. (2018). Domestication and Foreignization Strategies in Two Arabic Translations of Marlowe's Doctor Faustus: Culture-Bound Terms and Proper Names. Pertanika Journal of Social Sciences \& Humanities, 26(2), 1019- 1032

Baker, M.. (1992) In Other Words: A Course book on Translation. London and New York Routledge. https://doi.org/10.4324/9780203327579

Benson, M., Benson, E. \& Ilson, R.(1997).The BBI Combinatory Dictionary of English. Amsterdam and Philadelphia: John Benjamins Publishing Company.

Cowan, L. (1989). Towards a definition of collocation. (Doctoral dissertation), Concordia University, Montreal, Quebec, Canada.

Dickins, J., Hervey, S., \& Higgins, I. (2016). Thinking Arabic translation: A course in translation method: Arabic to English. Routledge. https://doi.org/10.4324/9781315471570

Emery, P. (1991). Collocation in Modern Standard Arabic. Journal of Arabic Linguistics, 23(1), $56-65$.

Firth, J.R (1957) Papers in Linguistics 1934-1951. London: Oxford University Press.

Gledhill, Christopher (2000a). Collocations in Science Writing (Vol. 22) . Gunter Narr.

Hatim, B. \&Munday, J. (2004). Translation: An advanced resource book. UK: Routledge applied linguistics. https://doi.org/10.4324/9780203501887

House, J. (1997). Translation quality assessment: A model revisited (Vol. 410). Gunter Narr Verlag.

Kalèdaitè, V., \& Palevičienè, L. (2008). Reflections of cultural patterns in collocations: what the lexical item neighbor-kaimynas in English and Lithuanian tells us. Lituanus: Lithuanian 
quarterly journal of arts and sciences. Chicago: Lituanus foundation, Vol. 54, nr. 3 (2008). 21-30.

Molina, L and Albir, A. H. (2002). Translation Technique Revisited: A Dynamic and Functionalist Approach. Spain: Universitat Autonoma da Barcelona. https://doi.org/10.7202/008033ar

Munday, J. (2001). Introducing Translation Studies, Theories and Applications, (London, New York: Routledge).

Newmark, P. (1988). A Textbook of Translation. London: Prentice Hall.

Newmark, P. (2001). Approaches to Translation. Shanghai: Sanghai Foreign Language Education Press.

Nida, E. (1969). Science of Translation. Language, 45, 483-498. https://doi.org/10.2307/411434

Nida, E. A. (1964). Toward a science of translating: with special reference to principles and procedures involved in Bible translating. Brill Archive.

O’Donoghue, Salla. (2005). Cognitive Changes in Reader-Evoked Frames: Culture-specific references in Edna O'Brien's The Country Girls and its Finnish translation. A Pro gradu Thesis in English. Department of Languages, University of Jyvaskyla.

Obeidat A. M. \& Mahadi T.S.T (2019). The Translation of Arabic Religious- Cultural Collocations in Literary Text into English: An Application of Domestication and Foreignization Strategies. International Journal of Humanities, Philosophy and Language, 2(6), 155-165. https://doi.org/10.35631/ijhpl.260013

Obeidat, E. S., \& Abu-Melhim, A. R. H. (2017). Foreignization and domestication in translating English-Arabic baby formula labels. British Journal of Humanities and Social Sciences, 17(2), 50-66.

Oxford Advanced Learner's Dictionary (2005), 7th edition, Wehmeier, S. (ed.), Oxford: Oxford University Press.

Paluszkiewicz-Misiaczek, M. (2005). Strategies and methods in dealing with culture specific expressions on the basis of Polish-English translations of certain administrative and institutional terms. Theory and Practice in English Studies, 3, 243-248.

Sharifabad, E. D., Yaqubi, M., \& Mahadi, T. S. T. (2013). The Application of Domestication and Foreignization Translation Strategies in English-Persian Translations of News Phrasal Verbs. Theory \& Practice in Language Studies, 3(1), 94-99. https://doi.org/10.4304/tpls.3.1.94-99

Shuttleworth, M. and Cowie, M. (1997). Dictionary of Translation Studies, Manchester: St. Jerome

Toury, G., (1995). Descriptive Translation Studies and Beyond. Amsterdam /Philadelphia: John Benjamins. https://doi.org/10.1075/btl.4

Van Poucke, P. (2012). Measuring foreignization in literary translation: An attempt to operationalize the concepts of foreignization. In H. Kemppanen, M. Janis, \& A. Belikova (Eds.), Domestication and foreignization in translation studies (pp. 139-157). Berlin, Germany: Frank \& Timme GmbH.

Venuti, L. (1995). The Translator's Invisibility: A History of Translation. London: Routledge. https://doi.org/10.4324/9780203360064

Wang, F. (2014). An approach to domestication and foreignization from the angle of cultural factors translation. Theory and Practice in Language Studies, 4(11), 2423. https://doi.org/10.4304/tpls.4.11.2423-2427 
IJoLLT Vol. 2, No. 2 (September) 2019

eISSN: 2637-0484

Yang, W. (2010). Brief Study on Domestication and Foreignization in Translation, Journal of Language Teaching and Research, 1(1), 77-80. https://doi.org/10.4304/jltr.1.1.77-80 